Cornell Law Library

Scholarship@Cornell Law: A Digital Repository

Cornell Law Faculty Publications

Faculty Scholarship

$1-1-1993$

\title{
Products Liability Cases on Appeal: An Empirical Study
}

Theodore Eisenberg

Cornell Law School, ted-eisenberg@lawschool.cornell.edu

James A. Henderson Jr.

Cornell Law School, jim-henderson@postoffice.law.cornell.edu

Follow this and additional works at: http://scholarship.law.cornell.edu/facpub

Part of the Applied Statistics Commons, Civil Procedure Commons, and the Products Liability Commons

\section{Recommended Citation}

Eisenberg, Theodore and Henderson, James A. Jr., "Products Liability Cases on Appeal: An Empirical Study" (1993). Cornell Law Faculty Publications. Paper 369.

http://scholarship.law.cornell.edu/facpub/369

This Article is brought to you for free and open access by the Faculty Scholarship at Scholarship@Cornell Law: A Digital Repository. It has been accepted for inclusion in Cornell Law Faculty Publications by an authorized administrator of Scholarship@Cornell Law: A Digital Repository. For more information, please contact jmp8@cornell.edu. 


\title{
Products Liability Cases on Appeal: An Empirical Study
}

\author{
Theodore Eisenberg ${ }^{1}$ and James A. Henderson, Jr. ${ }^{2}$
}

This article analyzes 1,100 opinions to find the determinants of products liability cases on appeal in state and federal courts. The strongest predictor of plaintiff success on appeal is whether the plaintiff prevailed in a jury trial. Other important factors are the defendant's status as manufacturer; wholesaler, or successor corporation; the plaintiff's degree of injury; and whether the case involved a failure-to-warn claim. The existence of a comparative negligence regime increases the tendency of appellate courts to affirm lower courts. These results allow rejection of a simple model in which pre- and posttrial settlement behavior filters out cases in which the results are clear. Under such a model, only a residue of close cases remains with no clear reason to expect results highly favorable either to products liability plaintiffs or defendants. Despite the importance of the processes that filter appeals, some identifiable factors still influence appeals.

Although many states restricted products liability law in the 1970s and 1980s, this area of law continues to be a prime target of tort reform efforts (e.g., S.640, 102d Cong., 1st Sess. [1991]). Even as reform efforts progressed, however, we knew little about the actual state of products liability litigation. As perceptions of increasing waves of successful products liability litigation grew, the law became increasingly favorable to defendants (Eisenberg and Henderson, 1992; Henderson and Eisenberg, 1990).

1 Theodore Eisenberg is professor of law, Comell Law School. He serves on the editorial board of the Law and Society Review and is editor-in-chief of a multivolume treatise on debtor and creditor law. He and Professor Henderson have previously published major empirical studies of products liability law. He is currently working on empirical studies of Japanese business reorganization law and jurors in capital cases.

2 James A. Henderson, Jr., is the Frank B. Ingersoll Professor of Law, Comell Law School. He is the coauthor of The Torts Process (3d ed., 1988) and Products Liability: Problems and Process (2d ed., 1992) and is currently serving as the coreponter for the American Law Institute's project restating the Law of Products Liability.

THE JUSTICE SYSTEM JOURNAL, Volume 16, Number 2 (1993) 
Our goal is neither to further the theme of a prodefendant trend nor to debate the merits of products liability reform. Rather, we seek to begin to fill another gap in our knowledge of how products liability law functions. This article addresses the determinants of products liability appeals. Are there systematic patterns in products liability opinions by state and federal appellate court judges that provide insights into the determinants of success on appeal?

We emphasize at the outset what such a study can and cannot accomplish. Unlike some of our other recent products liability research (Eisenberg and Henderson, 1992; Henderson and Eisenberg, 1990), this study is limited to published appellate products liability opinions rendered by state and federal appellate court judges. Given the substantial filtering processes that lead to cases yielding opinions, we hesitate to make sweeping claims about all products liability litigation based solely on published opinions (Eisenberg and Schwab, 1989; Olson, 1992). Most products liability cases settle (Eisenberg and Henderson, 1992: 746-57). Of those unsettled cases resolved by litigation, only a fraction are appealed. And not all appeals lead to published opinions. These forces lead to opinions in only a small fraction of products litigation. In 1988, for example, we estimate that of approximately 15,000 nonasbestos products liability cases terminated at the trial court level (including settlements), only about 400 published products opinions were written (Eisenberg and Henderson, 1992: 797) ${ }^{3}$ Thus, opinions were published in less than 3 percent of products liability cases terminated in that year.

The opinion rate is so low that one might ask, Is there any value to studying published opinions? Studying published opinions remains valuable for both practical and theoretical reasons. Each litigant who is unsatisfied with the trial court's disposition of a products liability case faces a decision whether to appeal. That decision is informed by an attorney's assessment of the state of the law. ${ }^{4}$ Hence, published opinions heavily influence the decision of whether to file an appeal. Products liability law as developed in published opinions also guides corporate law departments and plaintiffs' attorneys in deciding whether to bring, defend, or settle claims.

At theoretical and pedagogical levels, published opinions play a more dominant role. For most scholars, published opinions constitute the population of cases that shape perceptions of the legal system. "Published opinions are all most of us ever work from" (Eisenberg and Johnson, 1991: 1195). However interdisciplinary legal-teaching materials have become, for most nonstatutory courses (including products liability courses), the appellate opinion remains the basic unit of analysis and instruction (Henderson and Twerski, 1992). Furthermore, even though products liability appeals are neither a large fraction nor a random sample of filings, important trends observed in published opinions have been shown to match trends in the mass of trial court filings (Eisenberg and Henderson,

3 The 15,000 figure is arrived at as follows. We know that 5,897 federal district court nonasbestos products liability cases terminated in 1988 (Eisenberg and Henderson, 1992: 797 [Table A-2]). We estimate that federal cases compose about 39 percent of all products cases (Id.: 739.) Dividing the 5,897 federal cases by 39 percent yields a total national products case figure of 15,121 .

4 Economic factors, of course, also influence the decision whether to appeal, as do postrial court disposition settlement negotiations. 
1992; Henderson and Eisenberg, 1990). In light of published opinions' influence on the state of the law, perceptions of the law, and day-to-day decision making, the analysis of factors influencing appellate outcomes should be of interest.

We find that the strongest predictor of success on appeal is whether the plaintiff prevailed in a jury trial. Other important factors are the defendant's status as manufacturer, wholesaler, or successor corporation; the plaintiff's degree of injury; and whether the case involved a failure-to-warn claim. We also find that a comparative negligence regime increases the tendency of appellate courts to affirm the decisions of lower courts.

The published opinions screened for this study are the bulk of published state and federal appellate court opinions in products liability law, as reported in the Commerce Clearing House's Products Liability Reporter. Details about these data are reported elsewhere (Henderson and Eisenberg, 1990: 499-503, 518-22; Eisenberg and Henderson, 1992: 737-38). We include here only cases that involved an appeal by a traditional plaintiff or defendant and that clearly benefited plaintiffs or defendants. ${ }^{5}$ We view a party as benefiting when it views itself as a victor on appeal. In almost all cases, there is a high correlation between the formal disposition (affirmed, reversed, remanded, etc.) and what we are calling benefit. For example, when a plaintiff appeals and the appellate court reverses the trial court, it is likely that the appeal benefits the plaintiff. The years covered are 1983 to $1988 .^{\circ}$

It is helpful to describe two classes of hypotheses that might explain appellate outcomes. The first and most straightforward or intuitive hypothesis associates characteristics that seem favorable to one side with success for that side. For example, the doctrine of strict liability is believed to make it easier for plaintiffs to recover in products liability cases than traditional negligence doctrine. Hence, a straightforward hypothesis is that cases in which strict liability is available will have higher plaintiff appellate success rates than cases in which only negligence or related theories are available.

A second class of hypotheses, derived from selection effect theory (Eisenberg, 1990; Priest and Klein, 1984), take into account the filtering process that leads to the relatively few cases that are appealed. Under this view, strict liability might not correlate with high observed plaintiff success rates because the parties' pre- and posttrial settlement behavior filters out cases in which the results are clear. Only a residue of close cases remains with no clear reason to expect them to show results highly favorable to products plaintiffs or defendants.

Both intuitive and selection effect-based theories can claim some support in prior litigation studies. Broad case categories, such as products liability, do exhibit characteristics that transcend procedural stages. For example, classes of cases that fare relatively well

5 Some products liability appeals involve third-pany plaintiffs or defendants. These parties, though nominally plaintiffs or defendants, do not al ways correspond to the traditional notion of the injured party as plaintiff. In other products liability cases, the nominal plaintiff is not the injured pany. We limit our analysis to cases in which the appeal is by a traditional plaintiff —an injured pany —or a traditional defendant-the alleged wrongdoer or that person's insurer.

6 These are the years for which we gathered the most detailed information about opinions. Some of our other work spans more years (Eisenberg and Henderson, 1992: 737-38, opinions from 1979 through 1989). 
in pretrial dispositions also fare relatively well at trial (Eisenberg, 1991). And civil rights cases, which fare poorly at the trial level, also fare poorly on appeal (Eisenberg and Schwab, 1989). It is plausible, therefore, that some characteristics thought to influence motions to dismiss transcend that early procedural stage and continue to influence outcomes, even through trial and on appeal. ${ }^{7}$

It is also likely that the case-filtering process introduces new influences on appeal and muffles some factors that are influential at the trial court level. A study of race-based intent cases found that several factors that were significant in district court opinions lost significance or changed direction in appellate cases (Eisenberg and Johnson, 1991: 1191). For example, being certified as a class action strongly correlated with plaintiff success in the district court, a plausible result, but had little statistical interest on appeal. The strong class action cases may never have reached the appellate stage. Other variables increased their influence on appeal (Id.: 1191-92).

\section{The Data and Statistical Associations Between Pairs of Variables}

The average value for each variable considered in this study is set forth in Table 1 . The great bulk of cases, 86 percent, include manufacturers as defendants. Wholesalers and retailers in the chain of distribution are much less frequently involved. Plaintiffs are predominantly product users or employees, in contrast to bystanders, spouses, and business owners. The dominant defect considered in the opinions is the design defect (48 percent of opinions), though failure to warn before distribution also was considered frequently (36 percent). The most common harm suffered by plaintiffs was severe personal injury (41 percent), with death occurring in an additional 15 percent of opinions. The controversial recovery for emotional harm without physical impact was considered by courts in only 1 percent of cases. Appellate courts considered strict liability as a legal theory in nearly two-thirds of the cases, and negligence was considered in 41 percent of the cases.

Many of the cases were resolved after products reform statutes (42 percent) or tort reform statutes (14 percent) were in effect. A quarter of the cases were resolved when comparative negligence was in effect. In 27 percent of the appeals, plaintiffs had won jury verdicts, in 15 percent defendants had won such verdicts. Judges trying cases without juries resolved 2 percent of the cases for plaintiffs and an equal percentage for defendants. ${ }^{8}$ Fortyeight percent of the appeals were plaintiff appeals from nontrial dispositions. Because the trial court dispositions can only take on one value, 5 percent of the appeals were defendant appeals from nontrial dispositions. This imbalance in plaintiff/defendant nontrial disposi-

7 In race-based intent cases, the variables "clear pattern" (a method of proof) and "private status of defendant" are influential in both trial court and appellate opinions (Eisenberg and Johnson, 1991: 1192).

8 Judges trying cases without juries should be distinguished from judges adjudicating cases on the basis of pretrial motions. 


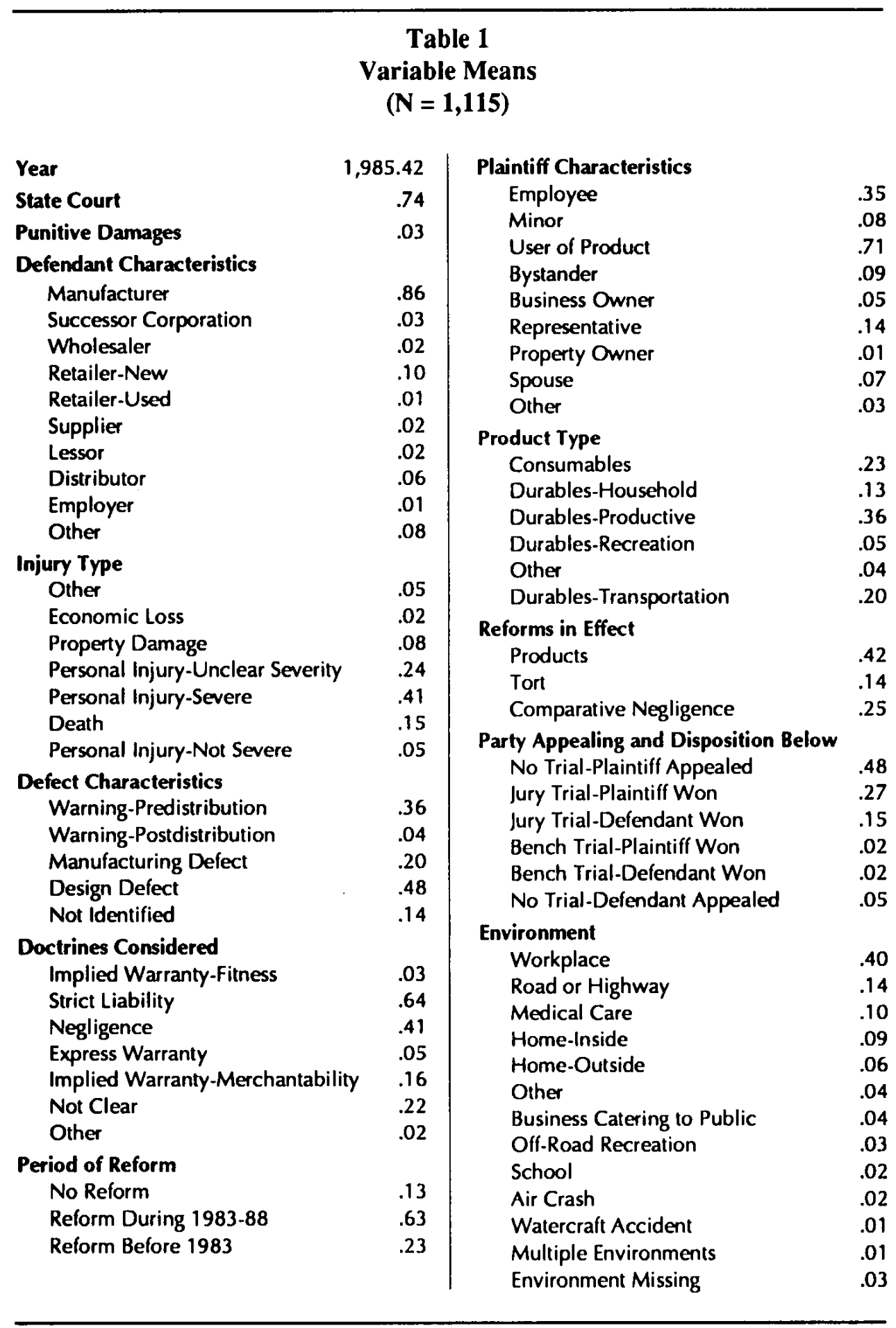


tion reflects the reality that, in cases that do not settle, defendants much more so than plaintiffs can prevail without a trial by making a pretrial motion. This dominance of pretrial dispositions on appeal confirms earlier similar findings (Chapper and Hanson, 1990).

We largely limit our consideration to the relationship between each factor and the appellate outcome. The factors considered are jurisdiction (to a limited extent), statutory environment, doctrinal theories applied, defect types considered, product type, lower court disposition, plaintiff and defendant characteristics, injury type, and environment in which the injury occurred. Part I discusses these influences in isolation of each other. Part II uses multivariate analysis to explore the influences simultaneously.

Our coding scheme differs from factor to factor. Most factors can take on multiple values. For example, a single case might involve doctrines of both strict liability and negligence. Manufacturers and retailers might appear as defendants in the same case. A few factors-severity of injury, product type, environment of injury, and lower court disposition-might take on only one value. The possible values for these variables appear in the tables below that present the influence of each factor on appellate outcome.

\section{Jurisdiction}

Because products liability law develops largely at the state level, it is natural to test whether, controlling for other factors, appellate outcomes differ from state to state. We report elsewhere the plaintiff success rates in published opinion cases for each state for the period 1979 to 1989 (Eisenberg and Henderson, 1992: 800). While interstate variation exists, state identity variables, as a group, provide little help in explaining appellate outcomes. ${ }^{9}$ This result seems to transcend jurisdiction in that the party benefiting did not differ between state and federal appellate courts. State courts account for 821 of the 1,115 opinions (73.6 percent) examined in this study. In state cases, plaintiffs benefited from 46.4 percent of the opinions; in federal cases, the rate was 46.9 percent.

\section{Statutory Environment}

Although products liability law developed as a common-law subject, it has been modified substantially by products liability reform statutes and by more generally applicable tort reform statutes. Because products reform usually means reform to curtail recoveries by plaintiffs, one might expect products reform statutes to lead to outcomes more favorable to defendants.

We group tort reform statutes into those applicable to torts genera'ly ("tort reform"), those applicable primarily to products liability ("products reform"), and those primarily affecting damages ("damages reform"). States with reform statutes were categorized based on the effective date of their reform provisions. Cases decided in a reform state were coded " 1 " if they were decided after the effective date of reform and " 0 " if they were decided before the effective date. The variables used to track effective dates are "tort reform in effect," “"products reform in effect," and "damages reform in effect." An aggregate variable,

9 Because these data are already available, and in the interest of saving space, we do not repor state-by-state results here. 
Table 2

Party Benefiting as a Function of Statutory Reform

A. Reforms in Effect

Products Reform

Tort Reform

Damages Reform

Any of Products, Tort or Damages

Comparative Negligence

B. Period of Reform

No Reform

Reform During 1983-88

Reform Before 1983

Chi-square Significance, $2 \mathrm{df}$

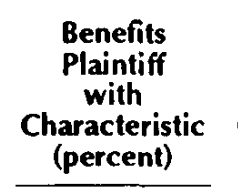

44.6

38.0

47.3

45.3

39.4

44.3

46.2

48.7

.671

\begin{tabular}{|c|c|c|}
\hline $\begin{array}{c}\text { Benefits } \\
\text { Plaintiff } \\
\text { without } \\
\text { Characteristic } \\
\text { (percent) }\end{array}$ & $\begin{array}{c}\text { Number } \\
\text { with } \\
\text { Characteristic }\end{array}$ & Significance \\
\hline 47.9 & 466 & .278 \\
\hline 48.0 & 158 & .020 \\
\hline 46.5 & 74 & .893 \\
\hline 47.7 & 543 & .417 \\
\hline 48.9 & 277 & .006 \\
\hline
\end{tabular}

$55.7 \quad 149$

$53.8 \quad 705$

$51.3 \quad 261$

"reform statute in effect," was coded " 1 " if any of the three categories of reform statutes were in effect at the time of the decision.

For each of the three types of reform statutes, we constructed variables to account for the time period of reform. "No reform" is " 1 " for states that enacted no reform measures, "reform during" is " 1 " for states that enacted any of the three kinds of reform measures from 1983 to 1988, and "reform before" is " 1 " for states with any of the three kinds of reform measures in effect before $1983 .{ }^{10}$

To further account for each state's statutory environment, we added two variables to track the state's experience with comparative negligence. During the 1970s and the 1980s many states, through statutes or judicial decisions, adopted or modified their rules on comparative negligence (Landes and Posner, 1987: 80-84). The variable "comparative negligence" was coded " 1 " if a state, through statute or decision, adopted comparative negligence and " 0 " if it did not. The variable "comparative negligence in effect" tracks whether each case was decided before or after the adoption of comparative negligence in the relevant state.

Table 2 presents the relationship between statutory reform and case outcomes. The first numerical column shows the percentage of opinions that benefit plaintiffs that also possess the characteristic listed in the text column. For example, 44.6 percent of opinions issued after a products liability reform statute was in effect benefited plaintiffs. The second numerical column shows the percentage of opinions that benefit plaintiffs that do not possess the characteristic listed in the text column. For example, 47.9 percent of opinions

10 We also explored variables to account for whether each type of reform statute (tort, products, and damages) was enacted during or before the period studied here. For example, "reform damages during" would be coded " 1 " for a state that enacted a damages reform statute between 1983 and 1988; "reform damages before" would be coded "1" for a state that enacted a damages reform statute before 1983. 
decided without a products liability reform statute in effect benefited plaintiffs. The "number with characteristic" column shows the number of opinions with the characteristic listed in the text column. The "significance" column shows the likelihood of observing the difference between the first two numerical columns by chance. The reported significance levels are based on the chi-square test of significance. Using the customary significance level of .05 , one cannot reject the hypothesis that the different "benefits plaintiff" rates in opinions with and without products liability reform statutes is simply a product of chance.

Two reform variables are of interest (see Table 2). As one might expect, the tortreform-in-effect variable correlates strongly and significantly with defendants benefiting. Plaintiffs benefited in 38.0 percent of opinions when a tort reform statute was in effect and 48.0 percent of opinions when a tort reform statute was not in effect. In a sample of this size, the different benefit rates are unlikely to have occurred by chance. The products-reformin-effect variable is more puzzling. Although the difference in benefit rates is small and of little statistical significance, it is in a proplaintiff direction. Perhaps the tort reforms in such states mask the effects of product reform or the parties adjusted their filing and settlement behavior in light of the reforms. There is also a weak correlation between the period of reform and appellate success rates. In light of the significance level of $.671,{ }^{11}$ one cannot reject the null hypothesis - that there is no difference in success rates across periods of reform.

While most variables behave consistently with common intuition about the way products law works, the comparative negligence variable does not. Under contributory negligence, any fault on the part of the plaintiff bars recovery. Under comparative negligence, the plaintiff's negligence is compared with that of the defendant. The plaintiff's negligence is not an absolute bar to recovery. Comparative negligence statutes, thus, allow plaintiffs to recover when they formerly would be barred from any recovery by the doctrine of contributory negligence. One would therefore expect having a comparative negligence statute in effect to be a proplaintiff factor. Yet, having a comparative negligence statute in effect correlates strongly and significantly with defendants' benefiting on appeal. A negative aspect, from the plaintiffs' perspective, is that comparative negligence can reduce the award to plaintiffs who could have successfully avoided a claim of contributory negligence. Despite this counterweight, it remains puzzling why the presence of comparative negligence should be such a prodefendant feature. We explore a plausible explanation of this result below.

\section{Doctrinal Theories and Defect Types}

We treat a legal doctrine as present in the case when a court explicitly applied it as a possible basis for the defendant's liability. One might expect cases in which strict liability was considered to be most favorable to plaintiffs. In such cases, plaintiffs need only show defect, harm, and causation. Cases in which negligence applied should be more favorable

11 Significance tests reported here involving only two variables use the chi-square distribution with one degree of freedom. For example, the significance levels in panel A of Table 2 use the chi-square distribution with one degree of freedom because only two items are being compared. In panel B, the significance level reported is for the collection of three "Period of Reform" variables, thereby increasing the degrees of freedom. 
Table 3

Party Benefiting as a Function of Defect Characteristics and Doctrines Considered

A. Doctrines Considered Strict Liability Implied Warranty-Merchantability Negligence Express Warranty Implied Warranty-Fitness

Not Clear Other Doctrine

B. Defect Characteristics Manufacturing Defect Failure to Warn-Postdistribution Design Defect

Failure to Warn-Predistribution Not Identified

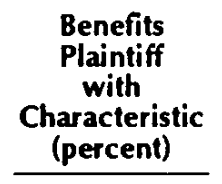

Benefits Plaintiff without Characteristic (percent)

\section{0}

45.3

44.8

43.4

42.4

36.6

19.0

49.6

47.9

46.8

43.9

42.8
40.4

46.8

47.7

46.7

46.7

49.3

47.1

45.8

46.5

46.4

48.0

47.2

$\begin{array}{ccc}\begin{array}{c}\text { Number } \\ \text { with } \\ \text { Characteristic }\end{array} & \text { Significance } \\ 716 & & .002 \\ 181 & & .714 \\ 453 & & .337 \\ 53 & & .637 \\ 33 & & .630 \\ 243 & & .000 \\ 21 & & .011\end{array}$

224

.313

.846

.894

.183

.302

to defendants because the defect must be a consequence of unreasonable behavior. Its mere existence is not enough. Implied warranty cases might be expected to fall somewhere in between strict liability and negligence. The defect types we accounted for are manufacturing defect, design defect, failure to warn (predistribution), and failure to warn (postdistribution). More than one defect type may be present in a single case.

With respect to legal doctrine, the principal result is that plaintiffs' chances of succeeding depend substantially on the availability of strict liability (see Table 3 ). It is the only doctrine with a success rate above the plaintiff average of 46.5 percent and is the only one (other than "not clear" and "other") with a highly statistically significant effect. This result squares well with intuition about how legal doctrine might affect cases' outcomes. Strict liability cases ought to be easier to win than other cases.

With respect to defects, there is only modest variation in plaintiff success rates. Indeed, one cannot reject the hypothesis that no alleged defect differs significantly from the mass of cases in correlating with plaintiff success. Nevertheless, the most proplaintiff defect, manufacturing, is the traditional bastion of products liability law. More-novel defect theories tend to fare less well.

\section{Product Category Variables}

Hundreds of products categories were aggregated into 21 major categories. Multivariate analyses, however, failed to find any significant relationships using these 21 categories. ${ }^{12}$ We further aggregated the product categories into six "super" categories: consumables,

12 For changes over time in plaintiff success rates for the more numerous categories, see Eisenberg and Henderson, 1992: 801. 
Table 4

Party Benefiting as a Function of Product Type

Product Type

Consumables

Durables-Household

Durables-Productive

Durables-Recreation

Durables-Transportation

Other

Chi-square Significance, $5 \mathrm{df}$

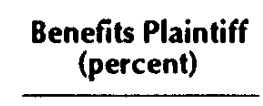

47.0

54.2

46.2

40.7

40.4

60.0

0.056

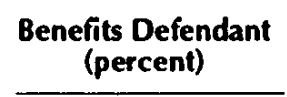

53.0

45.8

53.8

59.3

59.6

40.0
Number

253

142

396

54

225

45

durables-transportation, durables-household appliances, durables-recreation, durablesproductive, and other (see Table 4).

Of these larger categories, "durables-household" and "durables-transportation" stand out. Household durables correlate with plaintiff success while transportation durables correlate with defendant success. Perhaps courts became more protective of car, boat, and plane manufacturers than of other manufacturers. In addition, plaintiffs who are injured in transportation accidents may be willing to take a chance on a suit against the manufacturer under more marginal circumstances than would other products injury victims. Tort suits involving motor vehicles are a substantial fraction of all tort litigation, and the tendency to sue, even on weaker facts, may be greatest in this area (Hensler et al., 1991: 121).

\section{Lower Court Disposition}

Appellate courts tend to affirm lower courts (Eisenberg and Johnson, 1991: 1186, 1191). The party who appeals tends to lose; the party who prevailed in the trial court tends to prevail on appeal. In general, appellate rules require appellate courts to defer to findings of fact by trial courts. Appellate standard-of-review rules regarding deference to lower courts and the difficulty inherent in overturning a prior finding may render the lower court outcome an important predictor of appellate outcome. One way to address this issue is to account for who is appealing. In addition, we distinguish whether the appeal originated from a tried case or from other circumstances. The variables account for whether the appeal is from a judge trial or jury trial and which party prevailed. For those appeals not involving trials, we employ a variable ("plaintiff appealed, no trial") to reflect who is appealing.

When plaintiffs appealed, opinions benefited them in 37.4 percent of cases. When defendants appealed, opinions benefited them in 34.3 percent of cases (see Table 5).

These results are consistent with other studies of appellate litigation. Both the tendency to affirm and the reversal rates in the 30 to 40 percent range seem normal (Eisenberg and Schwab, 1989). But the products liability opinions also contain a special twist. The tendency to affirm the lower court emerges strongly in cases that reached trial, ${ }^{13}$ but not at all in cases resolved below without trial (see Panels B and C, Table 5). The tried case data 
Table 5

Party Benefiting as a Function of Party Appealing

\section{A. All Cases}

Plaintiff Appealed

Defendant Appealed

B. Cases Tried Below

Plaintiff Appealed

Defendant Appealed

C. Cases Not Tried Below

Plaintiff Appealed

Defendant Appealed

\begin{tabular}{c}
$\begin{array}{c}\text { Benefits } \\
\text { Plaintiff } \\
\text { (percent) }\end{array}$ \\
\hline 46.5 \\
37.4 \\
65.7 \\
56.0 \\
35.9 \\
70.1 \\
38.1 \\
38.0 \\
39.6
\end{tabular}

\begin{tabular}{|c|c|}
\hline Number & Significance \\
\hline \multicolumn{2}{|l|}{1,115} \\
\hline \multicolumn{2}{|l|}{754} \\
\hline 361 & .000 \\
\hline \multicolumn{2}{|l|}{525} \\
\hline \multicolumn{2}{|l|}{217} \\
\hline 308 & .000 \\
\hline \multicolumn{2}{|l|}{590} \\
\hline \multicolumn{2}{|l|}{537} \\
\hline 53 & .815 \\
\hline
\end{tabular}

show that the party appealing tends not to benefit on appeal. In cases not tried, opinions tend to benefit defendants regardless of whether the plaintiff or defendant appeals. Thus, appellate courts are reluctant to overturn trial verdicts for either plaintiffs or defendants. When cases did not reach the trial stage below, however, opinions favored defendants regardless of who appealed. All of the differences, other than that in untried cases, are highly statistically significant.

This distinction between tried cases and not tried cases is not reported in other studies of appellate opinions (Eisenberg and Schwab, 1989: 518; Wheeler et al., 1987). Within the products appeals realm, one might conclude that appellate judges show great deference to fact finders, hence the low reversal rate in tried cases. In cases not tried, less deference is conferred. The most unusual statistic is the high rate of prodefendant opinions in untried cases in which defendants appealed. But note that this is based on a relatively small number of cases (53).

The tendency to affirm also supplies insight into the initially surprising effect of comparative negligence regimes. Comparative negligence regimes tend to increase the affirmed effect for both plaintiffs and defendants (see Table 6). ${ }^{14}$ The shift is larger for defendants, but it is in the same direction for both groups. When plaintiffs appeal, absent comparative negligence, outcomes benefit defendants in 58.7 percent of the cases. When plaintiffs appeal, and comparative negligence is in effect, outcomes benefit defendants in 74.0 percent of the cases. A similar but smaller increase (from 64.5 to 69.4 percent)

13 It shows up in both cases tried before juries and cases tried before judges. Our data contain 50 judge-tried cases and 475 jury-tried cases with the necessary data; 9.5 percent of the trials were judge trials. The relative frequency of trial mode matches closely that found in a study of tried federal products cases (Clermont and Eisenberg, 1992: 1124,1141 [12.1 percent of products trials are jury trials]).

14 These effects show up whether one limits the sample to states in which there are both pre-and postcontributory negligence cases or whether one includes states that have never adopted comparative negligence in the sample. 
Table 6

Effect of Comparative Negligence as a Function of Party Appealing

\begin{tabular}{|c|c|c|c|c|}
\hline & $\begin{array}{l}\text { Benefits } \\
\text { Plaintiff } \\
\text { (percent) }\end{array}$ & $\begin{array}{c}\text { Benefits } \\
\text { Defendant } \\
\text { (percent) }\end{array}$ & Number & Significance \\
\hline A. Comparative Negligence Not in Effect & 48.9 & 51.1 & 838 & \\
\hline Plaintiff Appealed & 41.3 & 58.7 & 562 & \\
\hline Defendani Appealed & 64.5 & 35.5 & 276 & .000 \\
\hline B. Comparative Negligence in Effect & 39.4 & 60.6 & 277 & \\
\hline Plaintiff Appealed & 26.0 & 74.0 & 192 & \\
\hline Defendant Appealed & 69.4 & 30.6 & 85 & .000 \\
\hline
\end{tabular}

accompanies plaintiff appellate victories when defendants appeal. Thus, the earlier result that comparative negligence correlates with defendants' benefiting was a consequence of not distinguishing between appeals by plaintiffs and defendants. Defendants seemed to benefit because more plaintiffs appeal, appellate courts tend to affirm, and, under comparative negligence, this effect increases more for plaintiff appeals than for defendant appeals.

Comparative negligence's correlation with increased affirmance rates can be plausibly explained. Comparative negligence regimes provide a more finely tuned trial court result than do contributory negligence regimes. Fact finders need not make all-or-nothing decisions; they can apportion blame between plaintiff and defendant. This might result in less erroneous decision making. Regardless of whether comparative decision making improves trial court results, it results in more detailed fact finding, which is more resistant to appellate rebuff (Eisenberg and Johnson, 1991).

\section{Plaintiff and Defendant Characteristics}

Characteristics of plaintiffs and defendants often are believed to influence case outcomes. The seriously injured victim of a corporation's allegedly defective product generates pressure to manipulate doctrine to allow for recovery.

The most successful plaintiffs are, surprisingly, property owners, though they are involved in too few cases to be of much interest (see Table 7). Employees are the next most successful group, usually suing someone other than their employer because of workers' compensation barriers to employer liability. The employee class, though large, succeeds at a rate not much higher than other plaintiffs. Perhaps its success rate reflects a modest willingness by courts to reach out to manufacturers when employers are unavailable as defendants. Bystanders are the least successful plaintiff group, perhaps reflecting a carryover from earlier days when high-profile no-duty rules prevented bystanders from recovering. No plaintiff characteristic is highly statistically significant, and only the small property owner group departs from the overall plaintiff success mean of 46.5 percent by more than eight percentage points. Based on this analysis, one cannot reject the hypothesis that no plaintiff status substantially influences appellate courts. Alternatively, if one 
Table 7

Party Benefiting as a Function of Plaintiff and Defendant Characteristics

\begin{tabular}{|c|c|c|c|c|}
\hline \multicolumn{5}{|l|}{ Plaintiff Characteristics } \\
\hline Employee & 49.1 & 45.2 & 387 & .213 \\
\hline Minor & 41.6 & 47.0 & 89 & .327 \\
\hline User of Product & 47.6 & 44.0 & 790 & .274 \\
\hline Property Owner & 61.5 & 46.4 & 13 & .276 \\
\hline Bystander & 39.4 & 47.3 & 104 & .126 \\
\hline Spouse & 42.7 & 46.9 & 82 & .466 \\
\hline Business Owner & 48.1 & 46.5 & 54 & .809 \\
\hline Representative & 43.3 & 47.1 & 157 & .381 \\
\hline Other & 45.9 & 46.6 & 37 & .945 \\
\hline \multicolumn{5}{|c|}{ Defendant Characteristics } \\
\hline Manufacturer & 48.5 & 34.4 & 958 & .001 \\
\hline Successor Corporation & 22.9 & 47.3 & 35 & .004 \\
\hline Wholesaler & 25.0 & 46.9 & 20 & .051 \\
\hline Retailer-New Goods & 45.3 & 46.7 & 106 & .784 \\
\hline Retailer-Used Goods & 64.3 & 46.3 & 14 & .181 \\
\hline Supplier & 37.5 & 46.7 & 24 & .369 \\
\hline Lessor & 41.2 & 46.6 & 17 & .655 \\
\hline Distributor & 50.0 & 46.3 & 70 & .550 \\
\hline Employer & 46.2 & 46.6 & 13 & .977 \\
\hline Other & 31.8 & 47.8 & 88 & .004 \\
\hline
\end{tabular}

believes some of these factors do strongly influence the merits, the selection of cases for appeal may neutralize that tendency above the trial court level.

Defendant characteristics reveal a more interesting pattem. Defendant manufacturers, which appear in 86 percent of the cases, are the most vulnerable sizable group. Retailers of used goods and employers exceed manufacturers' loss rate on appeal, but they each appear only in about 1 percent of the appeals. Efforts to hold successor corporations and wholesalers liable fare poorly, and these results are highly statistically significant. The low plaintiff success rate in these defendant categories suggests that barriers to liability of remote parties may, in a manner parallel to the continuing bias against bystanders, linger despite the death of the privity requirement. ${ }^{15}$ In general, these parties are less involved with the production of a defective product and tend to do well on appeal. On the whole, defendant results support a straightforward hypothesis of courts being reluctant to push the boundaries of liability to new classes of defendants, despite occasional plaintiff efforts to do so.

15 When privity was required, an injured plaintiff could not sue a manufacturer if there were an intermediary, such as a retailer, between the plaintiff and manufacturer. 
Table 8

Party Benefiting as a Function of Injury Type

\begin{tabular}{|c|c|c|c|}
\hline & $\begin{array}{l}\text { Benefits Plaintiff } \\
\text { (percent) }\end{array}$ & $\begin{array}{c}\text { Benefits Defendant } \\
\text { (percent) }\end{array}$ & Number \\
\hline \multicolumn{4}{|l|}{ Type of Injury } \\
\hline Death & 44.6 & 55.4 & 166 \\
\hline Personal Injury-Severe & 52.2 & 47.8 & 458 \\
\hline Personal Injury-Not Severe & 43.1 & 56.9 & 58 \\
\hline Personal Injury-Unclear Severity & 38.1 & 61.9 & 265 \\
\hline Property Damage & 55.2 & 44.8 & 87 \\
\hline Economic Loss & 41.7 & 58.3 & 24 \\
\hline Other & 38.6 & 61.4 & 57 \\
\hline Chi-square Significance, $6 \mathrm{df}$ & .006 & & \\
\hline Total & & & 1,115 \\
\hline
\end{tabular}

\section{Injury Characteristics}

Severity of injury plays a substantial role in trial court adjudication (Danzon, 1985: 38 39). At the appellate level, substantial and significant differences exist. In constructing Table 8, we have limited each case to what we consider, somewhat arbitrarily, to be the most serious injury. Thus, each case has a unique injury designation. The table is arranged in descending order of seriousness of injury. Thus, for example, a case with both death and economic loss is classified as a death case. The type of injury as a whole shows significant differences, with property damage injuries having the highest success rates.

The injury results support both simple expectations about the injury/success relationship and a substantial selection effect. The high success rate for plaintiffs in cases involving property damage may be attributable to defendant or judicial reluctance to credit property claims in the trial courts; one needs personal injury to attract a sympathetic adjudicator. On the other hand, the difference between severe personal injury and personal injury that is not severe is as expected. Severe personal injury victims are more likely to win their cases than those with less severe injuries. Similarly, those plaintiffs seeking to recover for economic losses, other losses, or personal injuries of unclear severity fare worst on appeal. This result probably transcends the appellate process. Courts at all levels are reluctant to award damages for nonserious or novel damage claims.

\section{Environment of Product Use}

The environments in which products accidents occur (at least for appealed cases) are diverse, but they are neither home- nor consumer-dominated (see Table 9). The data provide little support for the view that injured consumers seeking recoveries for injuries from things like exploding soda bottles are a prominent feature of products liability law. The workplace accounts for nearly half of products liability opinions. Accidents around the home account for less than 20 percent of the opinions.

Taking all the environments together, one cannot reject the hypothesis that the environment does not correlate with appellate outcomes. Some individual environments, however, do stand out. Appellate plaintiffs benefit most in watercraft and school 
Table 9

Party Benefiting as a Function of Environment of Product Use

\section{Workplace}

Road or Highway

Medical Care

Home-Inside

Home-Outside

Other

Business Catering To Public

Off-Road Recreation

School

Air Crash

Watercraft Accident

Multiple Environments

Total

Chi-square Significance, $11 \mathrm{df}$

\begin{tabular}{c}
$\begin{array}{c}\text { Benefits Plaintiff } \\
\text { (percent) }\end{array}$ \\
\hline 48.6 \\
43.0 \\
40.4 \\
47.6 \\
36.1 \\
42.2 \\
56.1 \\
44.4 \\
62.5 \\
47.8 \\
75.0 \\
50.0 \\
46.7 \\
.158
\end{tabular}

environments and least in a medical environment or in accidents around, but outside, the home.

\section{The Relative Importance of Multiple Factors in Determining Success on Appeal}

The multiple influences on case outcomes suggest the use of statistical techniques that can determine the simultaneous effects of different factors on a given dependent variable. Two logistic regression models are developed and then applied to the data. ${ }^{16}$ In each model, the dependent variable, whether defendant benefited, is coded " 1 " if the defendant benefited from the appeal and " 0 " if the plaintiff benefited. In the first model, we include as independent variables the bulk of factors studied. The second model is limited to a smaller subset of variables that retain most of the explanatory power of the first model.

\section{The Full Model of Factors Influencing Success on Appeal}

The first numerical column in Table 10 shows each variable's "odds multiplier," a way of expressing the size of a variable's influence. ${ }^{17}$ To assess the magnitude of a variable's effect, multiply the odds of winning without the variable's presence by the variable's odds

16 Since, for present purposes, products cases either succeed or fail, the dependent variable is dichotomous, and we use logistic regression (Finkelstein and Levin, 1990: 48; Hosmer and Lemeshow, 1989).

17 Each coefficient estimates the corresponding variable's effect on the logarithm of the odds of the dependent variable, adjusting for all other variables included in the model. The odds multiplier is obtained by taking the antilog of the regression coefficient (Hosmer and Lemeshow, 1989: 58). The interpretation of the variable "year" differs because, unlike all other variables, it is continuous. For it the odds multiplier traces the effect of a unit increase (one year) in the variable. For a brief helpful explanation of logistic regression and its interpretation, see Kritzer et al., 1991: 538-39. 
Table 10

Logistic Regression: Dependent Variable = "Benefits Defendants"

\section{Year}

State Court

Punitive Damages

Defendant Characteristics*

Manufacturer

Successor Corporation

Wholesaler

Retailer-new

Retailer-used

Supplier

Lessor

Distributor

Employer

Other

Injury Type*

Other

Economic Loss

Property Damage

Personal Injury-Unclear

Personal Injury-Severe

Death

Personal injury-Not Severe (Ref.)

Defect Characteristics*

Warning-Predistribution

Warning-Postdistribution

Manufacturing Defect

Design Defect

Not Identified

Doctrines Considered*

Implied Warranty-Fitness

Strict Liability

Negligence

Express Warranty

Implied Warranty-Merchantability

Not Clear

Other

Plaintiff Characteristics*

Employee

Minor

User of Product

Bystander

Business Owner

Representative

Property Owner

Spouse

Other
Odds

Multiplier

1.11

.89

.41

.56

2.30

3.14

.62

.39

1.76

.63

.85

1.47

1.78

.56

.91

.51

.66

.47

.53

1.54

.84

1.13

1.34

1.29

.015

$.98 \quad .970$

.91

1.32

1.03

1.07

1.94

3.30

.80

1.04

1.09

1.26

.76

.95

1.92

1.56

3.22
Significance

.025

.499

.072

.002

.016

.078

.052

.062

.161

.277

.405

.562

.556

.038

.236

.202

.879

.146

.243

.030

.124

.169

.014

.620

.557

.105

322

.646

.083

.926

.724

.019

.055

.660

.235

.886

.656

.393

.511

.850

.349

.097

.050 
Product Type*

Consumables

Durables-Household

Durables-Productive

Durables-Recreation

Other

Durables-Transportation (Ref.)

Reforms in Effect*

Products

Tort

Comparative Negligence

State

Party Appealing and Disposition Below* No Trial-Plaintiff Appealed Jury Trial-Plaintiff Won Jury Trial-Defendant Won Bench Trial-Plaintiff Won Bench Trial-Defendant Won No Trial-Defendant Appealed (Ref.)

Environment*

Home-Outside

Watercraft

School

Medical

Comparative Negligence in Effect, Plaintiff Appealed

Comparative Negligence in Effect, Defendant Appealed

Constant

\begin{tabular}{|c|c|}
\hline $\begin{array}{c}\text { Odds } \\
\text { Multiplier }\end{array}$ & Significance \\
\hline .64 & .029 \\
\hline .55 & .014 \\
\hline .71 & .075 \\
\hline .77 & .446 \\
\hline \multirow[t]{2}{*}{.35} & .004 \\
\hline & .465 \\
\hline .92 & .572 \\
\hline 1.43 & .119 \\
\hline \multirow[t]{2}{*}{.90} & .579 \\
\hline & .000 \\
\hline .90 & .755 \\
\hline 1.42 & .341 \\
\hline .31 & .000 \\
\hline .50 & .208 \\
\hline \multirow[t]{2}{*}{1.16} & .810 \\
\hline & .142 \\
\hline 1.54 & 199 \\
\hline .42 & .187 \\
\hline .59 & .271 \\
\hline 1.45 & .184 \\
\hline 2.31 & .000 \\
\hline \multirow[t]{2}{*}{.76} & .373 \\
\hline & .026 \\
\hline
\end{tabular}

* Significance as group

multiplier. An odds multiplier of 1.0 indicates that the variable's presence does not change the odds of winning. An odds multiplier greater than 1.0 indicates that the variable's presence, holding other factors constant, increases the chances of winning. An odds multiplier of less than 1.0 indicates that, holding other factors constant, the presence of the factor reduces the chances of winning. The second numerical column opposite each variable, "significance," shows the probability that the observed result would occur by chance alone. ${ }^{18}$

The model in Table 10 includes most of the variables considered in Part I. To conserve space, we exclude some statutory reform variables summarized in Table 2 and all but four of the variables accounting for the environment in which the injury occurred. These variables would not materially affect the results.

18 The odds of winning should be distinguished from the probability of winning, even though the terms odds and probability often are informally used interchangeably (Eisenberg and Henderson, 1992: 807, n. 204). 
Note that the variable "year" is significant and prodefendant, as previously reported in our study using more opinions but less detailed information about each appellate opinion (Eisenberg and Henderson, 1992: 807). Thus, other factors that shape appellate outcomes do so against a recent background of increasingly prodefendant appellate decision making. Note also that the size and insignificance of the variable "state court" suggests, for purposes of this study, no noteworthy distinction between state courts and federal court appellate opinions. We also introduce a punitive damages variable for cases in which punitive damages were addressed in the appeal. It shows such cases to be proplaintiff but is of marginal statistical significance.

For the variables previously analyzed, the regression model shows that most of the effects survive multivariate analysis. The model fits the data reasonably well. ${ }^{19}$ It correctly predicts case outcomes in 69.7 percent (777) of the 1,115 cases. $^{20}$

19 Log Likelihood $=-652.74$. Model Chi-Square, $57 \mathrm{df}=234.91$, corresponding a significance level beyond .001 . On the goodness-of-fit measure, Chi-Square, $1,047 \mathrm{df}=1,122.75$, corresponding to a significance level of .051. Thus, one can nearly reject the hypothesis that the model is the "perfect" model for the data. In the model, however, the number of covariate pattems $(1,107)$ is close to the number of observations $(1,115)$, calling into doubt this measure of goodness-of-fit (Hosmer and Lemeshow, 1989: 138-40; Computing Resource Center, 1992: 16). Hosmer and Lemeshow suggest regrouping the data using predicted probabilities and forming ten percentile-based groups (1989: 142). This approach yields the following statistics:

$\begin{array}{ccc}\text { Group } & \text { Observed } & \text { Expected } \\ 1 & 14 & 16.97 \\ 2 & 24 & 29.59 \\ 3 & 41 & 39.60 \\ 4 & 52 & 49.53 \\ 5 & 66 & 59.04 \\ 6 & 69 & 65.77 \\ 7 & 75 & 72.85 \\ 8 & 79 & 79.35 \\ 9 & 84 & 87.26 \\ 10 & 92 & 96.02\end{array}$

(Table collapsed on percentiles of estimated probabilities)

$$
\text { Hosmer-Lemeshow Chi-Square, } 8 \mathrm{df}=6.45
$$

$$
\text { Significance }=0.597
$$

20 This represents a substantial improvement, almost 10 percent, over a logistic regression model using fewer variables on more cases (Eisenberg and Henderson, 1992: 807 [60.8 percent accuracy-of-prediction rate]). Hosmer and Lemeshow caution about using correct prediction percentages as a way of measuring the goodness of fit of a model (Hosmer and Lemeshow, 1989). A model of race-based intent case appellate opinions correctly described the outcome in 78.49 percent of 93 cases (Eisenberg and Johnson, 1991: 1196-97, column 2). The model's pseudo-R-square $=.15$. One should al so be cautious about using this measure (Hosmer and Lemeshow, 1989: 148).

Another measure of the model is its proporionate reduction in error (PRE). This is the reduction in error of the model being tested over a model in which one al ways chooses the mone dominant of the two outcomes. In this case, defendant benefiting is the more dominant outcome. If one always predicts defendant victory one would be correct in 596 out of 1,115 cases, or 53.4 percent. The prediction would be erroneous in the 519 cases that benefited plaintiffs. The model in Table 9 erroneously predicts outcomes in 338 cases. The PRE is the difference between the 519 erroneous predictions in the simplest model (predicting appellees always benefit) and 338, divided by 519 . Here the PRE is 34.9 percent. In a model analyzing 93 race-based intent opinions, the PRE was 47.4 percent (Eisenberg and Johnson, 1991: 1197 [calculation based on item 2]).

Given the affirmed effect, one might also compare the model with one in which the appellee always wins. If one always predicts appellee victory, one would be correct in 709 out of 1,115 cases, or 63.6 percent. The 


\section{Statutory Environment}

The statutory environment variables have been modified to reflect the relationship between comparative negligence and the affirmed effect. The "products reform in effect" and "tort reform in effect" reform variables tell much the same story as Table 2 . Tort reform favored defendants with a drop in its level of significance from .020 in Table 2 to .119 here.

To more fully account for the effect of comparative negligence, we constructed interaction variables for cases in which comparative negligence was in effect. The variable "comparative negligence in effect, plaintiff appealed" is coded "1" when comparative negligence was in effect and plaintiff appealed. The variable "comparative negligence in effect, defendant appealed" is " 1 " when comparative negligence was in effect and defendant appealed. The variable "comparative negligence state" is coded " 1 " for states that adopted comparative negligence during or before the period studied. These comparative negligence variables confirm the results described earlier (see Table 6). Plaintiff appeals in cases decided under comparative negligence correlate with defendant success. This result is significant beyond the .001 level. Defendant appeals under comparative negligence regimes correlate with plaintiff success. The direction of this effect is interesting, but the effect is not statistically significant. Thus, comparative negligence does not correlate simply with defendants' benefiting. It produces lower court results that are more difficult to overturn on appeal, regardless of whether the plaintiff or defendant is appealing.

\section{Trial Court Disposition}

For purposes of the regression model, we refined the analysis in Table 5 to take into account whether the trial below was a judge trial or jury trial. Appellate courts show a strong tendency to affirm both judge and jury trial results, with a somewhat stronger effect in the case of juries. The effect of a trial verdict is very powerful. For example, the variable, "jury trial, plaintiff won" has a noteworthy odds multiplier: 31 . Roughly speaking, holding other factors constant, the presence of a plaintiff jury verdict would reduce the defendant's odds of benefiting on appeal from, for example, 1:1 to .31:1, or from a 50 percent chance of winning to 24 percent chance. ${ }^{21}$ There is less than one chance in a thousand that one would observe this result by chance.

The jury verdict variable results show that the affirmed effect in tried cases survives, even when accounting for many other factors about the cases. In the case of jury trial verdicts for defendants and judge trial judgments for plaintiffs and defendants, the effects are all in the expected direction. Trial verdicts and judgments correlate with success on appeal. In the case of judge trials, the small number of trials may explain the failure to obtain greater statistical significance. Note also that when the trial court disposition was other than by trial, one cannot reject the hypothesis of no affirmed effect. The variable, "plaintiff appealed, no trial" has a small and insignificant odds multiplier.

prediction would be erroneous in the $\mathbf{4 0 6}$ cases that plaintiffs won. The PRE relative to this appellee-wins model is 16.7 percent.

21 Because logistic regression uses a nonlinear functional form, the effect of a change in each variable depends on the value of the other variables. 


\section{Defendant-Plaintiff Characteristics}

Table 10 confirms most of the interesting results reported in Table 7. The presence of manufacturers and used-product retailers as defendants correlate significantly or nearsignificantly with plaintiff success. The multivariate analysis suggests that new retailer defendants also correlate with plaintiffs benefiting. Wholesalers and successor corporations fare well as defendants. The weak showing by manufacturers and strong showing by successor corporations resonate with common intuition concerning how products defendants should fare. As suggested in Table 7, plaintiff effects, as a group, remain relatively small and insignificant.

\section{Defect Characteristics and Doctrines Considered}

No defect characteristic has a large and significant effect (see Table 3, panel B). Once other variables are accounted for, the variable "warning-predistribution" is prodefendant, large, and significant (see Table 10). The existence of doctrinal confusion attending failure-to-warn doctrine has been suggested elsewhere (Henderson and Twerski, 1990), and courts may be reluctant to push this unruly principle very far.

There also is some change in the effect of the "doctrines considered" variables. Strict liability, which is shown to be significantly proplaintiff (see Table 3, panel A), remains proplaintiff but loses even marginal statistical significance. ${ }^{22}$ Negligence doctrine remains prodefendant but now is significant at the .08 level. Cases in which doctrine is not clear remain highly prodefendant.

\section{Degree of Injury}

As a group, the injury variables are not statistically significant. But a noticeable and significant difference remains between "personal injury-severe" and "personal injury-not severe."

\section{Product Type}

"Durables transportation" products cases were significantly more difficult than other cases for plaintiffs to win on appeal (see Table 4).

\section{Environment}

The environment variables have reasonably large effects but appear in too few cases to preclude strong statistical significance.

\section{A More Parsimonious Model of the Factors Influencing Success on Appeal}

One can shift the focus of the data analysis away from a full model using all variables of interest. In Table 11, we have dropped groups of variables that were the least helpful in the

22 The change in "strict liability" is largely attributable to inclusion in the regression of the "not clear" variable in the "doctrines considered" grouping. Thus, if we exclude cases in which the doctrine is simply not clear, "strict liability" would retain its Table 2 characteristics. 
Table 11

Logistic Regression: Dependent Variable $=$ Benefits Defendants

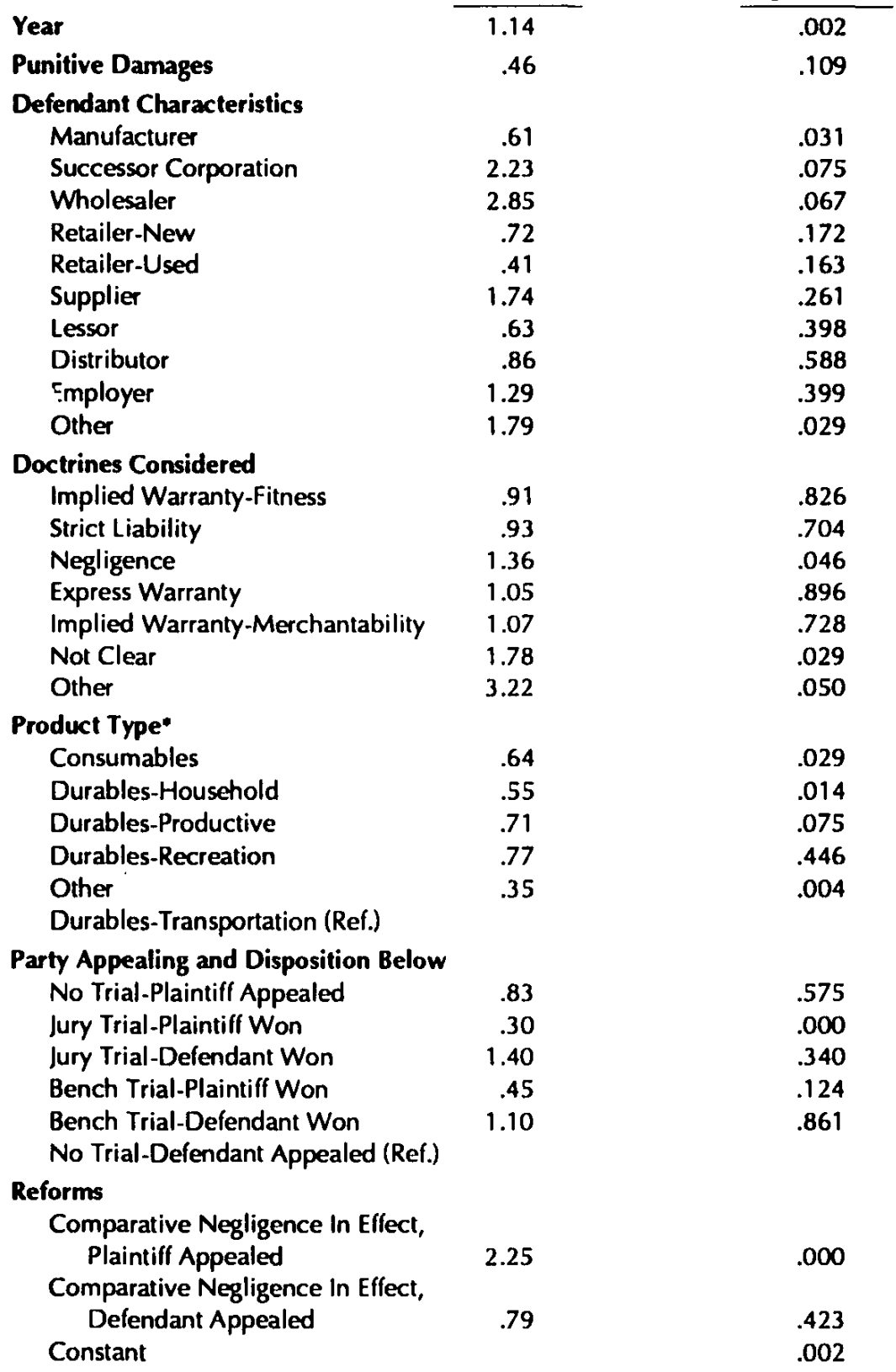

- Significance as a group 
larger model. These include the plaintiff variables, the defect variables, the injury variables, the reform status variables, and the environment variables.

This simpler model produces results substantially the same as the larger model. Variables retain their direction and approximate significance level. The model's fit to the data is not substantially different. ${ }^{23}$

\section{Conclusion}

Statistical analysis of a mass of cases can be a powerful technique for analyzing an area of law. A straightforward interpretation of these data is that novel doctrines and nonmanufacturing defendants are unlikely to yield plaintiff appellate victories. Products liability law is conservative in its insistence on traditional products doctrine and traditional defendants.

Are these appellate influences independent effects, or do they merely reflect trial court results? By controlling for who appealed, this study suggests that, despite the importance of the outcome below, other factors, such as defendant characteristics and the existence of comparative negligence, influence appeals. ${ }^{24}$

The data also suggest that procedural context matters. A plaintiff's surest route to victory on appeal is to have prevailed in a trial below. A similar effect emerges for defendants. But no similar effect emerges in cases not tried below. Appellate courts relatively infrequently overturn cases tried in lower courts but feel less constrained when no fact finding occurred below. This result may be unique to products liability appeals. jsj

23 Log Likelihood = -669.18. Model Chi-Square, $312 \mathrm{df}=202.04$, corresponding a significance level beyond .001 . On the goodness-of-fit measure, Chi-Square, $809 \mathrm{df}=890.01$, coresponding to a significance level of .025 . Thus, one can reject the hypothesis that the model is the "perfect" model for the data. This smaller model predicts results correctly in 68.4 percent of the cases.

24 Put another way, a model that does not account for who prevailed below yields substantially different results than the models presented here. Even in such models, however, the direction of the effect of the variables survives, and many of the significance levels are similar. 